\title{
The Effect of Zinc Treatment with The Prostaglandin (PGF2 $\alpha$ ) and TNF- $\alpha$ Level in Dysmenorrhea Patients
}

\author{
Setia Nisa, Vaulinne Basyir, Afriwardi
}

\begin{abstract}
Background: The aim of the study determine the effect of zinc treatment with the prostaglandin (PGF2 $\alpha$ ) and TNF- $\alpha$ level in dysmenorrhea patients. Methods: The study was conducted using a quasi experimental with pre-post test group design. The study was conducted at Piala Sakti School of Health Pariaman, West Sumatera Province, Indonesia from April-Mei 2018. The population in this study was teenagers with dysmenorrhea, sample size 22 people. Sampling technique with convenience sampling. This study used groups before treatment and after treatment of zinc treatment in the same group with a dose of $30 \mathrm{mg} /$ day for 3 days before pain. Test the normality of data by Shapiro-Wilk test and hypothesis test using paired $t$ test. A two-tailed $\boldsymbol{P}$-value of $<\mathbf{0 . 0 5}$ was considered statistically significant. Results: The results showed that the mean of prostaglandin level before treatment was $413.04 \pm 11.52 \mathrm{pg} / \mathrm{ml}$ after treatment $215.71 \pm 8.13 \mathrm{pg} / \mathrm{ml}$ and the mean of TNF- $\alpha$ level before treatment was $412.82 \pm 10.90 \mathrm{ng} / \mathrm{L}$ which after treatment $215.90 \pm 10.77 \mathrm{ng} / \mathrm{L}$, the analysis used was to determine the effect of zinc treatment with PGF2 $\alpha$ and TNF- $\alpha$ levels, using dependent $T$ test, from this analysis the results were obtained prostaglandin levels (PGF2 $\alpha$ ) with $P=0.001$ and TNF- $\alpha$ with $p=0.001(p<0.05)$ Conclusion: The conclusion of this study confirmed there was an effect of zinc treatment with the prostaglandin (PGF2 $\alpha$ ) and TNF- $\alpha$ in dysmenorrhea patients.
\end{abstract}

Index Terms-zinc, prostaglandin, TNF-a

\section{INTRODUCTION}

Dysmenorrhea is pain in the pelvic area due to menstruation and the production of prostaglandin (PGF2 $\alpha$ ) and TNF $\alpha$, often starting after experiencing the first menstruation (menarche). The prevalence of dysmenorrhea in each country has been carried out and shows various events. Australia shows a prevalence of $93 \%$ with moderate illness as much as $48 \%$ and strong illness as much as $21 \%$ [1]. Brazil is $86 \%$ with mild illness $25.5 \%$, moderate illness $46.9 \%$ and strong illness $27.6 \%$ [2]. Dysmenorrhea prevalence in Ethiopia is $85 \%$ [3], Ghana as much as $74.4 \%$ with a prevalence of mild illness as much as $18.1 \%$, moderate illness as much as $37.5 \%$, and strong illness as much as $18.8 \%$ [4]. Switzerland is $86 \%$ where $12 \%$ are women with strong pain and $74.1 \%$ moderate pain [5].

Setia Nisa Master of Biomedical Program, Faculty of Medicine Universitas Andalas, Padang City, Indonesia

Vaulinne Bsyir, Department of Obstetric and Gynaecology, Faculty of Medicine Universitas Andalas, Padang City, Indonesia

Afriwardi, Department of Physiology, Faculty of Medicine Universitas Andalas, Padang City, Indonesia.
Prevalence of dysmenorrhea in the southeast asia region $58.8 \%$ of women with dysmenorrhea in Vietnam with $2 \%$ strong pain, $23.3 \%$ moderate to strong pain, $6.5 \%$ moderate pain, and $7.8 \%$ mild to moderate pain. The prevalence of dysmenorrhea in Indonesia is $64.25 \%$ consisting of $54.89 \%$ of primary dysmenorrhoea and $9.36 \%$ of secondary dysmenorrhoea. Primary dysmenorrhea is about $60-70 \%$ of adolescents experience it, three quarters of these adolescents experience mild to severe pain, another quarter experience severe pain [6]. The prevalence of dysmenorrhea in Indonesia is quite high.

Several factors in the occurrence of dysmenorrhea in it are an increase in the synthesis of prostaglandin (PGF2 $\alpha$ ) and cytokines (TNF $\alpha$ ) which are important in addition to PGF2 $\alpha$ in the inflammatory process. Prevention that is commonly given to reduce menstrual pain is to provide both exogenous and endogenous antioxidants including Vitamin C, E, and A and micronutrient metal groups such as magnesium and zinc [7].

Zinc has an important role in regulating more than 300 metalloenzymes which function in physiological processes. Zinc deficiency is directly known to increase prostaglandin synthesis, inflammatory reactions, decrease sexual response, and protein damage [8]. Zinc has the ability to suppress the rate of synthesis of inflammatory factors, apoptosis and can be an antioxidant agent together with metalotionin. The inflammatory process in the endometrium can result in ischemic reactions in uterine tissue as a result of the myometrial contraction process [9].

The aim of the study determine the effect of zinc treatment with the prostaglandin (PGF2 $\alpha$ ) and TNF- $\alpha$ level in dysmenorrhea patients.

\section{MATERIALS AND METHODS}

\section{A. Study Design and Research Sample}

The study was conducted using a quasi experimental with pre-post test group design. The study was conducted at Piala Sakti School of Health Pariaman, West Sumatera Province, Indonesia from April-Mei 2018. The population in this study was teenagers with dysmenorrhea, sample size 22 people. Sampling technique with convenience sampling. This study used groups before treatment and after treatment of zinc treatment in the same group with a dose of $30 \mathrm{mg}$ / day for 3 days before pain. Test the normality of data by Shapiro-Wilk test and hypothesis test using paired $\mathrm{t}$ test. A two-tailed $P$-value of $<0.05$ was considered statistically significant. 


\section{B. Operational Definitions}

The variables of this study included independent variable is zinc treatment and dependent variable is prostaglandin (PGF2 $\alpha$ ) and TNF- $\alpha$ level in dysmenorrhea patients.

\section{Data Collection Technique}

This study was approved by the Ethical Committee of Medical Faculty, Universitas Andalas with registration number 283/KEP/FK/2018. The research tool in the form of a Numerical Rating Scale (NRS) to measure the scale of pain in which in this case, assessment of menstrual pain using a scale with the provisions of 0 (painless) and 10 (very painful) then the respondent points to the number of menstrual pain felt. In this study zinc was given a zinc trademark by Indofarma at a dose of $30 \mathrm{mg}$ for three days before the date of menstruation. On the first day of menstruation, blood is taken for prostaglandin (PGF2 $\alpha$ ) and TNF $\alpha$ examination.

\section{Data Analysis}

The quantitative variables were recorded as Mean $\pm \mathrm{SD}$, median and percentage. Test the normality of data by Shapiro-Wilk test and hypothesis test using paired t test. A two-tailed $P$-value of $<0.05$ was considered statistically significant. A two-tailed $P$-value of $<0.05$ was considered statistically significant. Data were analyzed using the Stata version 14.2 (Stata Corporation).

\section{RESULTS}

Characteristics of respondents (Table 1).

Table 1: Characteristics of respondents

\begin{tabular}{lc}
\hline \multicolumn{1}{c}{ Characteristics } & $\begin{array}{c}\text { Mean } \pm \text { SD } \\
(\mathbf{n = 2 2})\end{array}$ \\
\hline Age of menarche $($ years $)$ & $13.00 \pm 0.97$ \\
Body mass index $\left(\mathrm{kg} / \mathrm{m}^{2}\right)$ & $19.71 \pm 0.41$ \\
\hline
\end{tabular}

Table 1 showed age of menarche $13.00 \pm 0.97$ years and body mass index $19.71 \pm 0.41 \mathrm{~kg} / \mathrm{m}^{2}$.

Table 2: The effect of zinc treatment with the prostaglandin level in dysmenorrhea patients

\begin{tabular}{lccc}
\hline \multirow{2}{*}{ Variable } & \multicolumn{2}{c}{ Group } & \\
\cline { 2 - 3 } & $\begin{array}{c}\text { Before } \\
\text { Intervention } \\
(\text { Mean } \pm \text { SD) }\end{array}$ & $\begin{array}{c}\text { After } \\
\text { Intervention } \\
(\text { Mean } \pm \text { SD) }\end{array}$ & $\begin{array}{c}\text { p } \\
\text { value }\end{array}$ \\
\hline $\begin{array}{l}\text { PGF2 } \alpha \\
(\mathrm{pg} / \mathrm{ml})\end{array}$ & $413.04 \pm 11.52$ & $215.71 \pm 8.13$ & 0.001 \\
\hline
\end{tabular}

Table 2 showed the mean of PGF2 $\alpha$ before intervention is $413.04 \pm 11.52 \mathrm{pg} / \mathrm{ml}$ and after intervention $215.71 \pm 8.13$ $\mathrm{pg} / \mathrm{ml}$. There was an effect of zinc treatment with the prostaglandin (PGF2 $\alpha$ ) level in dysmenorrhea patients $(\mathrm{p}<0.05)$.
Table 3: The effect of zinc treatment with the TNF- $\alpha$ level in dysmenorrhea patients

\begin{tabular}{lccc}
\hline \multirow{2}{*}{ Variable } & \multicolumn{2}{c}{ Group } & \\
\cline { 2 - 3 } & $\begin{array}{c}\text { Before } \\
\text { Intervention } \\
(\text { Mean } \pm \text { SD) }\end{array}$ & $\begin{array}{c}\text { After } \\
\text { Intervention } \\
(\text { Mean } \pm \text { SD) }\end{array}$ & $\begin{array}{c}\mathbf{p} \\
\text { value }\end{array}$ \\
\hline $\begin{array}{l}\mathrm{TNF}-\alpha \\
(\mathrm{ng} / \mathrm{L})\end{array}$ & $412.82 \pm 10.90$ & $215.90 \pm 10.77$ & 0.001 \\
\hline
\end{tabular}

Table 3 showed the mean of TNF- $\alpha$ before intervention is $412.82 \pm 10.90 \mathrm{ng} / \mathrm{L}$ and after intervention $215.90 \pm 10.77 \mathrm{ng} / \mathrm{L}$. there was an effect of zinc treatment with the TNF- $\alpha$ level in dysmenorrhea patients.

\section{DISCUSSION}

The result showed the mean of PGF2 $\alpha$ before intervention is $413.04 \pm 11.52 \mathrm{pg} / \mathrm{ml}$ and after intervention $215.71 \pm 8.13 \mathrm{pg} / \mathrm{ml}$. There was an effect of zinc treatment with the prostaglandin (PGF2 $\alpha$ ) level in dysmenorrhea patients $(\mathrm{p}<0.05)$. The mean of TNF- $\alpha$ before intervention is $412.82 \pm 10.90 \mathrm{ng} / \mathrm{L}$ and after intervention $215.90 \pm 10.77 \mathrm{ng} / \mathrm{L}$. There was an effect of zinc treatment with the TNF- $\alpha$ level in dysmenorrhea patients $(\mathrm{p}<0.05)$.

In this study, it was seen that Prostaglandin (PGF2- $\alpha$ ) levels given zinc were lower than before zinc, because oral administration of zinc was known to have an inhibitory effect on prostaglandin synthesis enzymes because enzymes have an active side that can inhibit the rate of action of the enzyme. Zinc is also known to have anti-oxidant ability because it can bind free radicals so that the incidence of oxidative stress in cells can be reduced and inflammatory reactions do not occur. This physiological function improvement can directly reduce the degree of pain because zinc is able to provide a relaxing effect on the myometrial muscle or blood vessels.

The zinc dose used in this study was $30 \mathrm{mg}$ daily based on a previous study [10]. The difference with this study is the difference in the treatment of zinc given to different people by comparing the mean level of prostaglandin (PGF2) given zinc before pain, with a placebo with a zinc dose of $30 \mathrm{mg}$ given once a day, with a $\mathrm{p}$ value $=0.001$ this shows the effect of giving zinc to prostaglandin levels so that with zinc treatment can reduce menstrual pain.

Zinc supplementation in primary dysmenorrhoea has a significant value which is characterized by a $\mathrm{p}<0.05$, a number of studies have shown that zinc can prevent primary dysmenorrhoea. Some hypotheses about how zinc does it are by encouraging circulation to prevent the occurrence of ischemia and being able to reduce free radicals which are directly capable of suppressing or reducing inflammatory cytokines, one of which is TNF- $\alpha$, this results in a decrease in pain [11]

Dysmenorrhoea or menstrual pain can occur a very strong uterine contraction that can cause tissue ischemia so that there is expenditure of pain mediators such as prostaglandin. With zinc administration it is expected to improve circulation so that tissue ischemia can be prevented, zinc also regulates Cox-2, an enzyme involved in pain and inflammation, where zinc will reduce Cox-2 activity so that it can reduce prostaglandin synthesis and TNF- $\alpha$ level, zinc is also one of 
the nutrients which can increase the conversion of essential fatty acids as anti-inflammatory for prostaglandins [8].

Based on the description above it can be concluded that zinc administration can reduce prostaglandin (PGF2- $\alpha$ ) and TNF $\alpha$ levels which are agents responsible for stimulating the occurrence of myometrial contractions which stimulate vascular contraception which results in pain, from the results of the study showed that the average decrease prostaglandin values (PGF2 $\alpha$ ) also followed a decrease in the average value of $\mathrm{TNF} \alpha$ after being given zinc.

\section{CONCLUSION}

The conclusion of this study confirmed there was an effect of zinc treatment with the prostaglandin (PGF $2 \alpha)$ and TNF- $\alpha$ in dysmenorrhea patients.

\section{ACKNOWLEDGMENT}

We would like to thank all respondents who participated in this study.

\section{REFERENCES}

[1] Parker MA, Sneddon AE, Arbon. The menstrual disorder of teenagers (MDOT) study: determining typical menstrual patterns and menstrual disturbance in a large population-based study of Australian teenagers. BJOG. 2010; 117:185-92

[2] Fujiwara T, Nakata R. Young Japanese college students with dysmenorrhea have high frequency of irregular menstruation and premenstrual symptoms. The Open Medical Informatics Journal. 2007;1:8-11.

[3] Shiferaw MT, Wubshet M, Tegabu D. Menstrual problems and associated factors among students of Bahir Dar University, Amhara National Regional State, Ethiopia: A cross-sectional survey. Pan Afr Med J.2014; 17: 246

[4] Gjeorgjievski M, Cappell MS. Portal hypertensive gastropathy: A systematic review of the pathophysiology, clinical presentation, natural history and therapy. World J Hepatol. 2016; 8: 231-62.

[5] Sanctis VD, Elsedfy H, Soliman AT, Soliman N. Dysmenorrhea in adolescents and young adults: A review in different countries. Acta bio-medica: Atenei Parmensis. 2016; 87: 1-10.

[6] Zegeye DT, Megabiaw B, Mulu A. Age at menarche and the menstrual pattern of secondary school adolescents in northwest Ethiopia. BMC Women's Health. 2009:1-8.

[7] Ahir S, Mania-Pramanik J, Chavan V, Kerkar S, Samant-Mavani P, Nanavati R, Mehta P. Genetic variation in the promoter region of pro-inflammatory cytokine TNF- $\alpha$ in perinatal HIV transmission from Mumbai, India. Cytokine. 2015; 72(1):25-30.

[8] Singh A, Kiran D, Singh H, et al. Prevalence and severity of dysmenorrheal: a problem related to menstruation among first and second year female medical students. Indian J Physiol Pharmacol. 2008;52(4):389-97

[9] Kim J, Kim S, Jeon S, Hui Z, Kim Y, Im Y, et al. Anti-inflammatory effects of zinc in PMA-treated human gingival fibroblast cells. Med Oral Patol Oral Cir Bucal. 2015; 20: e180-e187.

[10] Eby GA. Zinc Treatment Prevent Dysmenorrhea. Medical Hypothese. Med Hyphotheses. 2007; 69:297-301.

[11] Thomaszewska E, Muszynski S, Dobrowolski P, Kwiecien M, Winiarska-Mieczan A, Swietlicka I, Wawrzyniak A. Effect Of Zinc Level Source (Zinc Oxide Vs Zinc Glycine) on Bone mechanical and geometric Parameters And Histimorphology In Male Ross 308Broiler-chicken. Rev Bras Cienc Avic. 2017; 19: 159-69 